DOI: 10.2478/v10014-008-0019-0

Agrovoc descriptors: glycine max; plant anatomy; tissue culture; crop yield; crop performance; somaclonal variation; genetic variation

Agris category code: F60; F01; F30

COBISS Code 1.01

\title{
Morphological and agronomic evaluation of tissue culture derived Indian soybean plants
}

\author{
R. RADHAKRISHNAN ${ }^{1}$, B.D.RANJITHA KUMARI ${ }^{2}$
}

Received: July 31, 2007; accepted: August 8, 2008.

Prispelo 31. julija 2007; sprejeto 8. avgusta 2008.

\section{ABSTRACT}

Somaclonal variation has become common for many plant species including soybean (Glycine $\max (\mathrm{L}$.) Merr). The present study was aimed to compare the morphological and yield characters of tissue culture derived and field grown soybean cultivar CO-3 (Coimbatore-3). With respect to the plants derived from tissue culture, the morphological characters such as length of roots, shoots, petioles, internodal region, number of leaf nodes, leaf area, fresh and dry weight of leaves and roots and yield contributing characters length of pods, number of flowers/ node, number of pods/ node, number of pods/ plant, number of seed aborted fruits and number of seeds/ pod were significantly $(p>0.05)$ varied from parent or field grown plants, except seed yield. Even the variation was observed in both the type of plants, since the difference was not too large. We conclude that tissue culture technique is not detrimental for plant growth and performance and which is widely used in many genetic engineering techniques.

Key words: soybean, morphological and yield character, somaclonal variation, tissue culture

\section{IZVLEČEK}

\section{MORFOLOŠKE IN AGRONOMSKE LASTNOSTI RASTLIN INDIJSKE SOJE, REGENERIRANIH IZ TKIVNIH KULTUR}

Somaklonska variabilnost je pri soji (Glycine max (L.) Merr) in mnogih drugih rastlinah med uporabljanimi viri genske variabilnosti. Namen te raziskave je bil preveriti pojavljanje variabilnosti med rastlinami dobljenimi iz tkivnih kultur pri soji cv. CO3 (Coimbatore 3). Avtorji so primerjali regenerirane rastline $s$ kontrolnimi rastlinami. Ugotovili so vrsto značilnih razlik pri morfoloških lastnostih, nas primer glede na dolžino korenin, poganjkov, petiol, internodijev in strokov. Poleg teh lastnosti so bile tudi razlike glede na število olistanih nodijev, število cvetov na nodij, strokov na nodij, strokov na rastlino, stevilo semen na strok, svežo in suho teža listov in korenin značilne $(p>0.05)$, razlike pa niso bile značilne glede na pridelek rastlin. Ker razlike niso bile velike, avtorji

1 Ph.D. Student, Dept. of Plant Science, Bharathidasan University, Trichirappalli-620024, Tamil Nadu, India.

2 Reader, Dept. of Plant Science, Bharathidasan University, Trichirappalli-620024, Tamil Nadu, India. Corresponding author email: ranjithakumari2004@yahoo.co.in, Phone: 00-91-4312407061, Fax: 00- 91-431 - 2407045. 
ugotavljajo, da spremembe zaradi somaklonske variabilnosti niso nujno škodljive za rastline.To je pomembno, saj se tehniko tkivnih kultur široko uporablja pri uporabi metod genskega inženiringa.

Ključne besede: soja, morfološke lastnosti, pridelek, somaklonska variabilnost, tkivne kulture

\section{INTRODUCTION}

Genetic variation is an essential component of any conventional crop breeding programme. Conventionally, plant breeders recombine the desired genes from crop varieties and related species by sexual hybridization and develop new cultivars with the desirable traits such as high yielding and resistance to disease, insect and pests and drought. They are now faced with an even greater challenge to sustain food production for the ever-growing human population. The adoption of new technologies such as plant tissue culture and recombinant DNA may help in achieving some of the goals to increase food production. There is a great potential of cell and tissue culture techniques in plant improvement provided plants can be readily regenerated in large numbers (Jain, 1998).

Soybean is an economically important plant and their regeneration from tissue culture has been difficult and recently it became routine. Plants regenerated from tissue culture have exhibited various morphological and biochemical variation due to mutations which is termed as somaclonal variation (Larkin and Scowcroft, 1981). Chromosomal aberrations ranging from changes in ploidy to whole chromosome loss have been demonstrated for tissue culture derived plants. Mutations at different stages like single gene, multigene, and cytoplasmic mutation have also been described previously by Lee and Phillips, 1988; Dahleen et al., 1991. Ranch and Palmer (1987) found 80 chromosomes in regenerated soybean progeny. Barwale and Widholm (1989) reported mixaploidy with chromosome counts ranging from 10 to 60. Freytag et al. (1989) described changes in leaf morphology and growth habit from indeterminate to determinate in organogenically regenerated soybean plants. Where as, three soybean genotypes were regenerated with the organogenic cultures which showed significant variability for plant height and yield, while differences in lodging and maturity were not significant (Graybosch et al., 1987; Wright et al., 1986) and the significance of yield differences between regenerated and control plants were low. Barwale and Widholm (1987) studied the morphology of $212 \mathrm{SC}_{3}$ families and $789 \mathrm{SC}_{4}$ families from nine soybean genotypes regenerated through both the embryogenic and organogenic culture. The variant phenotypes included chlorophyll deficiency, sterility, abnormal leaf morphology, abnormal leaf number and dwarf growth habit. Interestingly one variant phenotype with wrinkled leaf trait was found to be maternally inherited (Stephens et al., 1991a). However, the regenerated plants were not extensively evaluated for agronomic traits. The objective of this study was to test the presence of tissue culture derived variation in morphological and agronomic traits under field conditions in the plants regenerated by organogenesis. 


\section{MATERIALS AND METHODS}

\subsection{Plant material}

The certified seeds of Soybean cv. $\mathrm{CO} 3$ were obtained from Tamilnadu Agricultural University, Coimbatore, India and used as an initial explant for plant source.

\subsection{Seed sterilization and seed pretreatment}

The seeds were surface sterilized with $0.1 \% \mathrm{HgCl}_{2}$ solution for $5 \mathrm{~min}$ and $70 \%$ alcohol for $1 \mathrm{~min}$ and again washed thoroughly with distilled water for 5 times. The seeds were cultured in B5 medium (Gamborg et al., 1968) Supplemented with $1.0 \mathrm{mg} / \mathrm{L}$ Thidiazuron (TDZ) in aseptic condition and the $\mathrm{pH}$ of the medium was adjusted in to 5.8 by adding $0.1 \mathrm{~N} \mathrm{NaOH}$ or $0.1 \mathrm{~N} \mathrm{HCl}$ and $16 \mathrm{~h}$ light and $8 \mathrm{~h}$ dark photoperiod was maintained by cool fluorescent lamp.

\subsection{Tissue culture and plant regeneration}

The cotyledonary node with axillary buds were excised from seven days old seedlings and transferred in to $1.0 \mathrm{mg} / \mathrm{L}$ TDZ treated B5 medium. After three weeks, the regenerated plants were hardened in the mud cub and maintained in the growth chamber. The hardened plants were transferred in to the field after one week. At the same time, the healthy seeds were propagated in ten mud pots. The experiment was repeated thrice.

\subsection{Analysis of morphological and yield variation between somaclonal line and parent plants:}

Both somaclonal line and parent plants, morphological and yield characters like length of roots, shoots, petioles, internodal region and pods and then number of leaf nodes, number of flowers/ node, number of pods/ node, number of pods/ plant, number of seed aborted fruits, number of seeds/ pod, leaf area, fresh and dry weight of leaves and roots and seed weight were measured at over the seed maturation in the pod

\subsection{Statistical analysis}

Data from the experiment were analyzed by SPSS software, in which statistical significance was determined at the 0.05 probability level.

\section{RESULTS AND DISCUSSION}

Comparison of somaclonal lines (SC) with the parental cultivar CO3 showed significant variation $(\mathrm{p}<0.05)$ for length of roots, shoots, petioles, internodal region and pods and then number of leaf nodes, number of flowers/ node, number of pods/ node, number of pods/ plant, number of seed aborted fruits, number of seeds/ pod, leaf area, fresh and dry weight of leaves and roots, but not in seed weight.

The results presented in our study revealed that some morphological variations exhibited between somaclonal lines (SC) and parental cultivar CO3 (table 1). The length of roots, shoots, internodal regions, petioles and root fresh weight were highly reduced (above 50\%) in somaclonal lines than that of parent plants. In somaclonal plants, fresh and dry weight of leaf, leaf area and number of leaf node were reduced $(<25 \%)$ when compared with parent plants. The root dry weight was also reduced into 35\% compared with parent plants. The changes in plant height and leaf size among micropropagated plants have been reported to be the effect of somaclonal variation in some plant species (Ravindra et al., 2004). The high 
variability observed in micropropagated rhubarb PC49 might be triggered by the cytokinin during micropropagation (Yipeng et al., 2005). Due to the hormonal concentrations in the tissue culture medium, the somaclonal variations occured caused in soybean.

Table 1. Comparison of morphological characters of somaclonal lines and parent plants

\begin{tabular}{rlcc}
\hline S. No & \multicolumn{1}{c}{ Morphological characters } & Parent plants & Somaclonal line \\
\hline & & & \\
1. & Root length $(\mathrm{cm})$ & $38.03 \pm 0.15$ & $14.32 \pm 0.17$ \\
2. & Shoot length (cm) & $123.43 \pm 0.21$ & $53.82 \pm 0.25$ \\
3. & No. of leaf nodes & $10.13 \pm 0.25$ & $7.92 \pm 0.23$ \\
4. & Length of internodal region(cm) & $8.81 \pm 0.24$ & $4.27 \pm 0.23$ \\
5. & Length of petiole (cm) & $12.18 \pm 0.17$ & $6.2 \pm 0.18$ \\
6. & Leaf area (cm) & $1681.58 \pm 25.1$ & $1264.61 \pm 45.7$ \\
7. & Leaf fresh weight (g) & $1.22 \pm 0.14$ & $0.88 \pm 0.14$ \\
8. & Leaf dry weight (g) & $0.260 \pm 0.02$ & $0.21 \pm 0.16$ \\
9. & Root fresh weight (g) & $0.274 \pm 0.03$ & $0.112 \pm 0.01$ \\
10. & Root dry weight (g) & $0.028 \pm 0.06$ & $0.018 \pm 0.00$ \\
& & & \\
\end{tabular}

The yield characters, number of flowers/ nodal region, number of pods/ nodal region, length of pods and number of seeds (table 2) were less significant variations between somaclonal lines and parent plants. The number of pods/ plants and percentage of seed aborted fruits were increased 30\% in somaclonal lines than that of parent plants. The number of pods in somaclonal lines were more than parent plants, which had equalized the yield reduction. In oil palm, woody tropical crop species, field evaluation of tissue culture derived plants revealed the occurrence of variant palms which show an abnormal flower development preventing fruit set (Duval et al., 1995).

Table 2. Comparison of yield contributing characters of somaclonal lines and parent plants

\begin{tabular}{llcc}
\hline S. No & \multicolumn{1}{c}{ Yield characters } & Parent plants & Somaclonal line \\
\hline & & & \\
1. & No. of flowers/ nodal region & $3.43 \pm 0.07$ & $2.47 \pm 0.10$ \\
2. & No. of pods / nodal region & $2.19 \pm 0.13$ & $1.25 \pm 0.16$ \\
3. & No. of pods / plants & $6.86 \pm 0.10$ & $8.85 \pm 0.16$ \\
4. & Length of pod (cm) & $4.06 \pm 0.15$ & $3.32 \pm 0.12$ \\
5. & No. of seeds / pod & $2.27 \pm 0.10$ & $1.78 \pm 0.09$ \\
6. & Seed weight (g) & $0.101 \pm 0.01$ & $0.092 \pm 0.05$ \\
7. & Seed aborted fruits (\%) & 61.98 & 73.42 \\
\hline
\end{tabular}

The seed weight was slightly reduced (less than 10\%) in somaclonal lines when compared to that of parent plants. Stephens et al., (1991b) also showed same results in soybean cultivar A3127, which is in consistence to the results of Graybosch et al. 
(1987), who showed a less variation in yield for some of the regenerated soybean lines. The normal appearance and small differences in the variants suggest that several genes or a minor gene may have been altered. If chromosome aberrations were present or if genes responsible for qualitative traits had been altered, we would expect to see abnormal plants and greater variation (Stephens et al., 1991b). The frequency of somaclonal variation would depend on the culture protocol applied during the in vitro process, particularly on the hormone composition of the medium and the number of subcultures. (Ducos et al., 2003).

The results presented here showed that soybean plants cultured through an organogenic regeneration procedure would not necessarily have detrimental mutations resulting from the tissue culturing process and would retain the yield potential of the parental cultivar. The results showed that somaclonal variation did cause significant beneficial variation.

\section{Acknowledgement}

We are grateful to thank Bharathidasan University, Tiruchirappalli, India for providing us financial support through University research studentship.

\section{REFERENCES}

Barwale, U.B., Widholm, J.M. 1987. Somaclonal variation in plants regenerated from cultures of soybean. Plant Cell Rep., 6: 365368.

Barwale, U.B., Widholm, J.M. 1989. Soybean: plant regeneration and somaclonal variation in soybeans. In: Bajaj YPS (Eds), Biotechnology in agriculture and forestry, 3: pp. 114-133.

Dahleen, L.S., Stuthman, D.D. Rines, H.W. 1991. Agronomic trait variation in oat lines derived from tissue culture. Crop Sci., 31: 90-94.

Ducos, J.P., Alenton, R., Reano, J.F., Kanchanomai, C., Deshayes1, A. Petiard, V. 2003. Agronomic performance of Coffea canephora P. trees derived from large-scale somatic embryo production in liquid medium. Euphytica, 131: 215-223.

Duval, Y., Engelmann, F. Durand-Gasselin, T. 1995. Somatic embryogenesis in oil palm (Elaeis guineensis Jacq). In: Y.P.S. Bajaj (Eds), Biotechnology in Agriculture and Forestry : Somatic embryogenesis and synthetic seed, 30: pp. 335-352.

Freytag, A.H., Rao-Arelli, A.P., Anand, S.C., Wrather, J.A. Owens, L.D. 1989. Somoclonal variation in soybean plants regenerated from tissue culture. Plant Cell Rep., 8: 199- 202.

Gamborg, O.L., Miller, R.A. Ojima, K. 1968. Nutrients requirements of suspension cultures of soybean root cells. Exp. Cell Res., 50: 151-158.

Graybosch, R.A., Edge, M.E. Delannay, X. 1987. Somaclonal variation in soybean plants regenerated from the cotyledonary node tissue culture system. Crop Sci., 27: 803806. 
Jain, S.M. 1998. Plant biotechnology and mutagenesis for sustainable crop improvement. In: R.K. Behl, D.K. Singh \& G.P. Lodhi (Eds.), Crop Improvement for Stress Tolerance, , CCSHAU, Hissar \& MMB, New Delhi, India. pp. 218-232.

Larkin, P.J., Scowcroft, W.R. 1981. Somaclonal variation - a novel source of variability from cell cultures for plant improvement. Theor. Appl. Genet., 60: 197-214.

Lee, M., Phillips, R.L. 1988. The chromosomal basis of somaclonal variation. In: Briggs WR (Eds) Annu Rev Plant Physiol Plant Mol Biol 39: pp. 413-437.

Ranch, J.P., Palmer, R.G. 1987. A ploidy variant regenerated from embryogenic tissue cultures of soybean. Soybean Genet. Newsl., 14: 161- 163.

Ravindra N.S., Kulkarni, R.N., Gayathri, M.C., Ramesh, S. 2004. Somaclonal variation for some morphological traits, herb yield, essential oil content and essential oil composition in an Indian cultivar of rose-scented geranium. Plant Breed., 123: 84-86

Stephens, P.A., Barwale-Zehr, U.B., Nickell, C.D. Widholm, J.M. 1991a. A cytoplasmicallyinherited, wrinkled-leaf mutant in soybean. J. Hered., 82:71-73.

Stephens, P.A., Nickel, C.D., Widholm, J.M. 1991b. Agronomic evaluation of tissue-culturederived soybean plants. Theor. Appl. Genet., 82: 633-635.

Wright, M.S., Koehler, S.M., Hinchee, M.A., Carries, M.G. 1986. Plant regeneration by organogenesis in Glycine max. Plant Cell Rep., 5: 150-154.

Yipeng, Z., Brian, W., Grout, W., Peter, C. 2005. Variations in morphology and disease susceptibility of micropropagated rhubarb (Rheum rhaponticum) PC49, compared to conventional plants. Plant Cell, Tissue and Organ Culture, 82: 357-361. 